\title{
ANTECEDENTS OF WORK ENGAGEMENT IN A MULTINATIONAL OIL COMPANY
}

\author{
AL OLIVIER \\ S ROTHMANN \\ Ian.Rothmann@nwu.ac.za \\ WorkWell, Research Unit for People, Policy and Performance \\ North-West University, Potchefstroom
}

\begin{abstract}
The objective of this study was to investigate the antecedents of work engagement. Stratified random samples ( $N=171)$ were taken of employees in a multinational oil company. The Work Engagement Scale and the Work Experiences Scale were administered. The results confirmed that psychological meaningfulness and psychological availability were significant predictors of work engagement. Psychological meaningfulness displayed the strongest positive relationship with engagement. The relationship of co-worker relations and work role fit with work engagement was mediated by the psychological condition of meaningfulness. Cognitive, emotional and physical resources had the strongest effect on psychological availability. Co-worker relations and co-worker norms predicted psychological safety. The relationship between resources and work engagement was mediated by the psychological condition of availability. .
\end{abstract}

Key words: Work engagement, psychological meaningfulness, psychological safety, psychological availability, antecedents

The workplace has changed over the past decade and most organisations have to survive in a competitive global economy. Their survival depend on their ability to satisfy customer needs, while achieving quality, flexibility, innovation and organisational responsibility, through the engagement and commitment of employees (Fay \& Luhrmann 2004; Newell, 2002). It is important for managers to cultivate work engagement, given that disengagement or alienation is central to the problem of worker's lack of commitment (Bleeker \& Roodt, 2002; Schaufeli \& Bakker, 2004). According to Kahn (1990), work engagement involves the expression of the self through work and other employee-role activities.

May, Gilson and Harter (2004) stated that there are practical reasons (e.g. turnover and customer satisfaction) as well as humanistic reasons (motivation and attachment to work) for managers and researchers of organisations to be concerned with work engagement. Harter (2001) found a substantial correlation between work engagement and business outcomes. Highly engaged individuals were most often found in the highperformance units. According to Harter (2001), employees want to engage with work that has meaning and is an extension of their personalities and dreams.

Previous studies regarding work engagement have focused on the reliability and validity of measuring instruments thereof (Barkhuizen \& Rothmann, 2006; Storm \& Rothmann, 2003), the relationship between burnout and work engagement (Coetzer \& Rothmann, 2007), and the effect of job demands and job resources on work engagement (Rothmann \& Jordaan, 2006). According to Brown (1996), research on job involvement has neglected to examine the role of psychological conditions identified by Kahn (1990) and May et al. (2004). They stated that engagement is different from job involvement in that it is concerned more with how the individual employs him-/herself during the performance of his/her job.

This study attempts to explore work engagement and psychological conditions with the focus on understanding the mediating effects of conditions such as psychological meaningfulness, availability and safety on work engagement in a multinational oil company. The company has been implementing change initiatives consistently over a three year period, including streamlining of business processes across its Pan African operations, downsizing, relocation of employees, and outsourcing of non-core business activities and standardisation of processes to meet global standards.

\section{Work engagement}

Work engagement is defined as "the harnessing of organisation members' selves to their work roles [by which they] employ and express themselves physically, cognitively and emotionally during role performances" (Kahn, 1990, p. 694). Therefore, engaged employees become physically involved in their tasks, cognitively alert, and emotionally connected to others when performing their jobs. Personal disengagement is described as the uncoupling from the work roles. According to Kahn (1990, p. 700), work engagement entails "the simultaneous employment and expression of a person's 'preferred self' in task behaviours that promote connections to work and to others." In contrast, disengaged employees become disconnected from their jobs and hide their true identity, thoughts and feelings during role performances.

Engagement is generally defined as an energetic state in which the employee is dedicated to excellent performance at work and is confident of his or her effectiveness (Naude \& Rothmann, 2006). According to the analysis of Maslach, Schaufeli and Leiter (2001), work engagement is distinct from constructs such as organisational commitment, job satisfaction, or job involvement. While organisational commitment refers to an employee's association with the organisation that provides employment, the focus is on the organisation, whereas engagement focuses on the work itself. Job satisfaction is the extent to which work is a source of need fulfilment and contentment, or a means of freeing employees from hassles or dissatisfaction; it does not encompass the person's relationship with the work itself. Job involvement is similar to the involvement aspect of engagement with work, but does not include the energy and effectiveness dimensions (Brown, 1996; Van Wyk, Boshoff \& Cilliers, 2003).

May et al. (2004) conceptualised engagement by emphasising the importance of people bringing their physical, emotional and cognitive resources to bear on role-related tasks when they engage themselves at work. They argue that most jobs entail some level of physical exertion and challenges, as well as emotional (exhaustion) and cognitive demands, varying by job and person. 


\section{Psychological conditions and work engagement}

Kahn's (1990) studied how people's experiences of themselves and their work context influenced moments of personal engagement and disengagement. He argued that people ask themselves three fundamental questions in each role situation: a) How meaningful is it for me to bring myself into this performance? b) How safe is it to do so? c) How available am I to do so? According to Kahn (1990), these three psychological conditions affect employees' engagement.

Psychological meaningfulness refers to "a feeling that one is receiving a return on investment of one's self in a currency of physical, cognitive, or emotional energy" (Kahn, 1990, p. 703-704). Psychological meaningfulness has to do with how valuable a work goal is in relation to an individual's own ideals or standards. According to Thomas and Velthouse (1990), meaningless work may often cause apathy and detachment from one's work. When individuals are disengaged from their work, they can also be estranged from themselves (Seeman, 1972). An organisation has a responsibility towards its employees to provide meaningful work to them because that can lead to their personal growth and motivation (Spreitzer, Kizilos \& Nason, 1997).

The following hypothesis is formulated regarding the relationship between psychological meaningfulness and work engagement: Hypothesis 1a: Psychological meaningfulness is positively related to work engagement.

Psychological meaningfulness occurs when individuals feel useful and valuable, and is influenced by work-role fit and rewarding interpersonal interactions with co-workers. A perceived "fit" between an individual's self-concept and his/her role will lead to an experienced sense of meaning, due to the ability of the individual to express his/her values and beliefs (Strümpfer 2003). Shamir (1991) states that people are not just goal orientated, they can express themselves in a creative way. People have unique self-concepts and they want to express these and therefore seek roles in which they can do so. Individuals will also experience greater meaning in their work if they have rewarding interpersonal interactions with co-workers (Locke $\&$ Taylor, 1990). Individuals will tend to experience a sense of meaningfulness if they are treated with respect, dignity and appreciation for their contributions. Co-worker interactions create a sense of belonging and a stronger sense of social identity. The opposite is also true. According to Florian and Snowden (1989), a loss of social identity can lead to meaninglessness.

The following hypotheses are formulated regarding the relationship between psychological meaningfulness, work role fit and supportive co-worker relations:

Hypothesis 1b: Work role fit is positively related to psychological meaningfulness.

Hypothesis 1c: Co-worker relations are positively related to psychological meaningfulness.

Psychological safety is defined as "feeling able to show and employ oneself without fear of negative consequences to selfimage, status, or career" (Kahn, 1990, p. 708). Psychological safety is believed to lead to engagement, because it reflects one's belief that a person can employ him-/herself without fear of negative consequences. Supporting and trusting supervisory and co-worker relations as well as flexibility in behavioural norms lead to feelings of psychological safety (May et al., 2004). Individuals with rewarding interpersonal interactions, as well as the presence of co-worker interactions that foster a sense of belonging and stronger sense of social identity should experience increased psychological safety (Kahn 1990).

The following hypothesis is formulated regarding the relationship between psychological safety and work engagement:

Hypothesis 2a: Psychological safety is positively related to work engagement.
An individual's relationship with his supervisor has a direct impact on how safe he feels in the work environment. Edmondson (1999) stated that when a supervisor is supportive and not controlling at work, his employees will experience a sense of safety in the work environment. These supervisors are concerned about their employees' needs and feelings, provide positive feedback to them and develop new skills as well as encourage employees to voice their opinions, whether positive or negative.

Trusting and supportive interpersonal relations among employees at work should lead to psychological safety (Kahn, 1990). Interpersonal trust can either have cognitive or affective bases (McAllister, 1995). The reliability and dependability of others are related to cognitive-based trust, where the emotional relationships between individuals impact on affective trust.

Behaviour, attitudes and the emotional dimensions of work, are governed by norms in organisations (Hochschild, 1983). Kahn (1990) stated that as long as individuals stay within the boundaries of acceptable behaviour at work, they will experience psychological safety. It is further theorized that norms are enforced if: (i) they facilitate the survival of a group, (ii) make group member behaviour more predictable, (iii) assist the group to avoid embarrassing interpersonal problems, and (iv) express the central values of the group.

The following hypotheses are formulated regarding the relationship between psychological safety, supervisory relations, co-worker relations and co-worker norms:

Hypothesis 2b: Supervisory relations are positively related to psychological safety.

Hypothesis 2c: Co-worker relations are positively related to psychological safety.

Hypothesis 2d: Co-worker norms are positively related to psychological safety.

Psychological availability refers to "the sense of having the physical, emotional or psychological resources to engage at a particular moment." (Kahn, 1990, p. 714). Psychological availability is influenced by physical energy, emotional energy, insecurity (e.g. lack of self-confidence, heightened selfconsciousness and ambivalence about fit with the organisation), and non-work events.

The following hypothesis is formulated regarding the relationship between psychological availability and work engagement: Hypothesis 3a: Psychological availability is positively related to work engagement.

All individuals have physical, emotional and cognitive resources to perform their tasks with at work. Some jobs are less physically challenging than others, like sitting at a desk, which can also put enormous stress on the back (Hollenbeck, Ilgen \& Crampton, 1992). Individuals vary in their levels of stamina, flexibility and strength to meet these physical challenges. If they lack these physical resources, they may become disengaged from their work. All the jobs don't have the same emotional demands. Some jobs require much more emotional labour, such as the services sector (Hochschild, 1983; Sutton, 1991). Cognitive demands and resources also vary per person and per job. Some job roles require more information processing than some individuals can handle. These individuals become overwhelmed by the amount of information they have to handle and their inability to think clearly. It is expected that the availability of resources will lead to greater engagement.

Self-consciousness about how others perceive and judge a person at work is also perceived to play a role with regards to psychological availability (Schlenker, 1980). It is likely that a person with high self-consciousness will be more focused on external cues and is likely to get distracted. 
The following hypotheses are formulated regarding the relationship between psychological availability, resources, and self-consciousness:

Hypothesis 3b: Resources are positively related to psychological availability.

Hypothesis 3c: Self-consciousness is negatively related to psychological availability.

It is theorised that the three psychological conditions which are explored, namely psychological meaningfulness, psychological safety and psychological availability, will influence the degree of engagement in one's work function. If individuals see work roles as being meaningful to them, they will most likely engage more in it. Psychological safety should also lead to engagement at work, because it confirms the individual's belief that she can voice her opinion without facing any negative consequences. Where the environment of an individual is ambiguous, unpredictable and threatening, it is very likely that they will disengage from work. Individuals should be more willing to engage themselves in their roles at work if they believe that they have the necessary physical, emotional and cognitive resources to do that (May et al, 2004).

Therefore, the following research hypotheses are formulated regarding the relationships between the antecedent conditions, psychological conditions and work engagement:

Hypothesis 4a: Psychological meaningfulness mediates the relationship between work role fit and co-worker relations, on the one hand and work engagement.

Hypothesis 4b: Psychological safety mediates the relationship between supervisory relations, co-worker relations and coworker norms, and work engagement.

Hypothesis 4c: Psychological availability mediates the relationship between resources and self-consciousness and work engagement.

\section{RESEARCH DESIGN}

\section{Research approach}

A cross-sectional survey design was used in this study. Questionnaires were used to gather data in a no-random field survey.

\section{Research method \\ Participants}

The participants were employees of a multinational oil company based at different locations across South Africa. Random sampling was used to send the questionnaire to 200 employees, of which 171 participated. Participation was voluntary and confidentiality was maintained. Employees from all departments, job groups and educational levels ranging from semi-skilled to professional were included. The respondents were mostly female $(67,3 \%)$, married $(58,5 \%)$ and English speaking (69\%). The majority of respondents fell into the $31-40$ years age group (59\%), with the minority $(7,6 \%)$ of respondents older than 50 years. Educational level revealed that the majority $(49,1 \%)$ of participants have a Grade 10 , 11, 12 qualification. The majority of participants worked for the company for 6-10 years (40\%) and mostly permanent employees $(97,1 \%)$ participated in the survey.

The characteristics of the participants are reported in Table 1.

\section{Measuring instruments}

Two measuring instruments were used for the purposes of this study, namely the Work Engagement Scale and the Work Experiences Scale (May et al., 2004).

The Work Engagement Scale as developed by May et al. (2004) was used to gather information about how employees react to various aspects of their work and their work situation. All items used for the scale, used a 5-point agreement-disagreement
Likert format varying from 1 (strongly disagree) to 5 (strongly agree). The items reflected each of the three components of Kahn's (1990) conceptualisation of psychological engagement, namely cognitive, emotional and physical engagement. Work engagement was measured by 13 items $(\alpha=0,77)$. Structural equation modelling was used to test the factorial model of work engagement. The results showed that a one-factor model $\left(\chi^{2}=\right.$ 42,27; $\chi^{2} / \mathrm{df}=2,11 ; \mathrm{GFI}=0,95 ; \mathrm{AGFI}=0,90 ; \mathrm{CFI}=0,90 ;$ RMSEA $=$ $0,08)$ was superior to a three-factor model. The one-factor model included eight items, inclusive of all three aspects of engagement (cognitive, emotional and physical) as operationalised by May et al. (2004)

TABLE 1

Characteristics of Participants ( $\mathbf{N}=\mathbf{1 7 1})$

\begin{tabular}{|c|c|c|c|}
\hline Item & Category & Frequency & Percentage \\
\hline \multirow[t]{2}{*}{ Gender } & Male & 56 & 32,7 \\
\hline & Female & 115 & 67,3 \\
\hline \multirow[t]{5}{*}{ Marital status } & Single/widow/widower & 36 & 21,1 \\
\hline & Engaged/in a relationship & 15 & 8,8 \\
\hline & Married/Remarried & 100 & 58,5 \\
\hline & Divorced & 17 & 9,9 \\
\hline & Separate & 3 & 1,8 \\
\hline \multirow[t]{6}{*}{ Language } & Afrikaans & 27 & 15,8 \\
\hline & English & 118 & 69,0 \\
\hline & Xhosa & 8 & 4,7 \\
\hline & Sotho & 6 & 3,5 \\
\hline & Zulu & 5 & 2,9 \\
\hline & Other & 7 & 4,1 \\
\hline \multirow[t]{4}{*}{ Age } & $20-30$ years & 24 & 14,0 \\
\hline & $31-40$ years & 59 & 34,5 \\
\hline & 41-50 years & 57 & 33,3 \\
\hline & Older than 50 years & 13 & 7,6 \\
\hline \multirow[t]{3}{*}{ Education level } & Grade $10,11,12$ & 84 & 49,1 \\
\hline & 3 year degree & 42 & 24,6 \\
\hline & 4 year degree and more & 45 & 26,3 \\
\hline \multirow[t]{5}{*}{ Years of employment } & $1-5$ years & 33 & 19,3 \\
\hline & $6-10$ years & 40 & 23,4 \\
\hline & $11-15$ years & 23 & 13,4 \\
\hline & $16-20$ years & 10 & 5,8 \\
\hline & 21 years and more & 21 & 12,4 \\
\hline
\end{tabular}

The Work Experiences Scale was used to measure Work Role Fit $(\alpha=0,92)$, Co-worker Relations $(\alpha=0,93)$ and Co-worker Norm Adherence $(\alpha=0,61)$ and were measured by 3-10 items. Supportive supervisor relations was measured by 10 items with $\alpha=0,95$. The alpha coefficients for resources, and selfconsciousness varied between 0,83 and 0,91 . Factor analysis of the variables identified 14 factors with eigenvalues larger than one. The largest factor explained $23,9 \%$ of the variance and was composed of all the supervisor relations items. All scale items loaded on their respective constructs and did not cross-load on the other factors.

The Work Experiences Scale of May et al. (2004) has not been used in the South African context and for this study all the subscales were included, i.e. Psychological Meaningfulness was measured by six items (e.g. "The work I do is very important to me"). Psychological Safety was measured by 3 items (e.g. "I'm not afraid to be myself at work"). Psychological Availability was measured by averaging 5 items (e.g. "I am confident in my ability to think clearly at work"). A principal component analysis was conducted on the 14 items of the psychological processes (conditions) subscale of the Work Engagement Questionnaire. The results showed that three factors (explaining $65,48 \%$ of the variance) had eigenvalues larger than one as confirmed and suggested by the scree plot. A principal axis factor analysis with a direct oblimin rotation was subsequently carried out and resulted in the following 
factors being included: Psychological Meaningfulness (6 items), Psychological Availability (5 items) and Psychological Safety (2 items). The alpha coefficients for the psychological conditions, namely Psychological Meaningfulness, Psychological Safety and Psychological Availability items varied between 0,71 and 0,90 in the study of May et al. (2004).

Work role fit was measured by 4 items, rewarding coworker relations by 10 items, supportive supervisor relations by 10 items, co-worker norms by 3 items. The degree to which individuals possess the resources to become available for engagement was assessed by averaging 8 items. Selfconsciousness was measured by 3 items and outside activities was measured by a single item. Three items measuring "job insecurity" were added to the questionnaire. A principal component analysis was conducted on the 41 items of the Job/Personal Characteristics subscale of the Work Experience Questionnaire. The results showed that eight factors had eigenvalues larger than one (explaining $73,91 \%$ of the variance), but the scree plot suggested that 7 factors could be extracted. Principal axis factors analysis (with a varimax rotation) was subsequently conducted, and resulted in the following factors: Supervisor Relations, Co-worker Relations, Resources, Work Role Fit, Job Insecurity, Self-consciousness and Co-worker Norms. Two factors, namely Self-consciousness and Co-worker Norms had only two items with loadings higher than 0,30 . One item of each these factors (which had loadings lower than 0,30 ) were excluded from further analysis.

Specific questions were included to gather information about the demographic characteristics of the participants, such as: gender, marital status, language, age, educational level, years of employment at the company and employment type.

\section{Statistical analyses}

The statistical analyses were carried out with the SPSS program (SPSS, 2003). Cronbach alpha coefficients $(\alpha)$ were used to assess the internal consistency of the measuring instruments (Clark \& Watson, 1995). Pearson correlation coefficients were used to specify the relationships between the variables. Descriptive statistics (e.g. means and standard deviations) were used to analyse the data. Pearson product-moment correlation coefficients were used to assess the relationships between the variables. Multiple regression analyses were used to investigate whether job/personal characteristics predict (e.g. work role fit) the psychological conditions (e.g. psychological meaningfulness), and whether these predict work engagement. In terms of significance, it was decided to set the value at a 95\% confidence interval level $(p<0,05)$. Effect sizes (Steyn, 1999) were used to decide on the practical significance of the findings. A cut-off point of 0,30 (medium effect, Cohen,
1988) was set for the practical significance of correlation coefficients.

\section{RESULTS}

\section{Descriptive statistics and correlations}

The descriptive statistics, alpha coefficients, and correlation coefficients of the scales of the measuring instruments are reported in Table 2.

The Cronbach alpha coefficients were obtained on all the measuring scales, varying from 0,41 to 0,92 . The Cronbach alpha coefficient of Psychological Safety $(\alpha=0,41)$ was lower than the guideline of 0,70 (Nunnally \& Bernstein 1994), and was consequently excluded from statistical analysis. Therefore, it was not possible to test Hypothesis 2.

A statistically significant correlation was found between Psychological Meaningfulness and Work Engagement $(r=$ $0,59, p<0,05$; large effect). Work Role Fit was statistically significantly related to Psychological Meaningfulness $(r=0,68, p$ $<0,05$; large effect). Furthermore, Psychological Meaningfulness was statistically significantly related to Co-worker Relations. Hypotheses $1 \mathrm{a}, \mathrm{b}$ and $\mathrm{c}$ are therefore accepted.

A statistically significant correlation was found between Psychological Safety and Work Engagement $(r=0,17, p<$ $0,05)$. Supervisor Relations and Psychological Safety were also statistically significantly related $(r=0,39, p<0,05$; medium effect). Co-worker Relations was statistically significantly related to Psychological Safety ( $r=0,32, p<0,05$; medium effect). Furthermore, Psychological Safety was statistically significantly related to Co-worker Norms $(r=0,20, p<0,05)$. Hypotheses $2 \mathrm{a}$, $\mathrm{b}, \mathrm{c}$, and $\mathrm{d}$ are therefore accepted.

A statistically significant correlation was also found between Psychological Availability and Work Engagement $(r=0,34, p<$ 0,05 ; medium effect). Resources was statistically significantly related to Psychological Availability $(r=0,45, p<0,05$; medium effect). Furthermore, Psychological Availability was statistically significantly negatively related to Selfconsciousness $(r=-0,40, p<0,05)$. Hypotheses $3 \mathrm{a}, \mathrm{b}$, and $\mathrm{c}$ are therefore accepted.

\section{Multiple regression analyses}

Multiple regression analyses were carried out with Psychological Meaningfulness and Psychological Availability (as measured by the Work Experience Questionnaire) as independent variables and Work Engagement (as measured by the Work Engagement Questionnaire) as dependent variable (see Table 3).

TABLE 2

DESCRIPTIVE STATISTICS AND PRODUCT-MOMENT CORRELATIONS

\begin{tabular}{|c|c|c|c|c|c|c|c|c|c|c|c|c|c|}
\hline Scale & Mean & SD & $\alpha$ & 1 & 2 & 3 & 4 & 5 & 6 & 7 & 8 & 9 & 10 \\
\hline 1. Psychological Meaningfulness & 23,95 & 4,90 & 0,92 & - & - & - & - & - & - & - & - & - & - \\
\hline 2. Psychological Availability & 20,87 & 3,17 & 0,85 & $0,40^{*}+$ & - & - & - & - & - & - & - & - & - \\
\hline 3. Psychological Safety & 7,46 & 1,96 & 0,41 & 0,27 * & 0,21 * & - & - & - & - & - & - & - & - \\
\hline 4. Work Role Fit & 12,66 & 4,10 & 0,90 & $0,68 *++$ & $0,39^{*}+$ & $0,28^{*}$ & - & - & - & - & - & - & - \\
\hline 5. Co-worker Relations & 36,31 & 8,42 & 0,95 & $0,31 *+$ & $0,38^{*}+$ & $0,32{ }^{*}+$ & $0,36^{*}+$ & - & - & - & - & - & - \\
\hline 6. Supervisor Relations & 32,50 & 10,36 & 0,96 & $0,15^{*}$ & 0,09 & $0,39^{*}+$ & 0,28 * & $0,42^{*}+$ & - & - & - & - & - \\
\hline 7. Resources & 25,67 & 7,39 & 0,91 & $0,37{ }^{*}+$ & $0,45^{*+}$ & $0,41^{*}+$ & $0,40^{*}+$ & $0,30^{*+}$ & $0,30^{*+}$ & - & - & - & - \\
\hline 8. Co-worker Norms & 7,00 & 1,70 & 0,71 & 0,29 * & 0,17 * & $0,20^{*}$ & $0,34^{*}+$ & $0,29 *$ & $0,39^{*}+$ & $0,32 *+$ & - & - & - \\
\hline 9. Self-consciousness & 5,27 & 2,40 & 0,86 & $-0,15^{*}$ & $-0,40^{*}+$ & $-0,18^{*}$ & $-0,17^{*}$ & $-0,25^{*}$ & 0,08 & $-0,31^{*}+$ & 0,08 & - & - \\
\hline 10. Job Insecurity & 8,85 & 3,84 & 0,91 & $-0,07$ & $-0,21^{*}$ & $-0,26^{*}$ & $-0,11^{*}$ & $-0,13^{*}$ & $-0,04$ & $-0,19^{*}$ & $0,10^{*}$ & $0,37^{*}+$ & - \\
\hline 11. Work Engagement & 31,40 & 4,46 & 0,72 & $0,59 *++$ & $0,34^{*+}$ & $0,17^{*}$ & $0,35^{*}+$ & $0,25^{*}$ & $0,12 *$ & 0,21 * & 0,23 * & $-0,11$ * & $-0,07$ \\
\hline
\end{tabular}

${ }^{*} p<0,05$ - statistically significant 
TABLE 3

REGRESSION ANALYSIS WITH PSYCHOLOGICAL CONDITIONS AS INDEPENDENT VARIABLES AND WORK ENGAGEMENT AS DEPENDENT VARIABLE

\begin{tabular}{|c|c|c|c|c|c|c|c|c|c|c|}
\hline \multicolumn{2}{|c|}{ Model } & \multicolumn{2}{|c|}{$\begin{array}{l}\text { Unstandardised } \\
\text { Coefficients }\end{array}$} & \multirow{2}{*}{$\begin{array}{c}\begin{array}{c}\text { Standardised } \\
\text { Coefficients }\end{array} \\
\text { Beta }\end{array}$} & \multirow[t]{2}{*}{$t$} & \multirow[t]{2}{*}{$p$} & \multirow[t]{2}{*}{$\boldsymbol{F}$} & \multirow[t]{2}{*}{$R$} & \multirow[t]{2}{*}{$R^{2}$} & \multirow[t]{2}{*}{$\Delta R^{2}$} \\
\hline & & B & SE & & & & & & & \\
\hline & & & & & & & $5,29 *$ & 0,17 & 0,03 & 0,03 \\
\hline \multirow[t]{2}{*}{1} & Constant & 28,45 & 1,33 & & 21,45 & $0,00 *$ & & & & \\
\hline & Psychological Safety & 0,40 & 0,17 & 0,17 & 2,30 & 0,23 & & & & \\
\hline \multirow[t]{5}{*}{2} & & & & & & & $12,26^{*}$ & 0,36 & 0,13 & $0,10^{*}$ \\
\hline & (Constant) & 20,21 & 2,15 & & 8,83 & $0,00^{*}$ & & & & \\
\hline & Psychological Safety & 0,24 & 0,17 & 0,11 & 1,46 & 0,15 & & & & \\
\hline & Psychological Availability & 0,45 & 0,10 & 0,32 & 4,32 & $0,00^{*}$ & & & & \\
\hline & & & & & & & $32,26^{*}$ & 0,61 & 0,37 & 0,24 * \\
\hline \multirow[t]{4}{*}{2} & (Constant) & 15,88 & 2,03 & & 7,83 & $0,00^{*}$ & & & & \\
\hline & Psychological Safety & 0,01 & 0,15 & 0,00 & 0,05 & 0,96 & & & & \\
\hline & Psychological Availability & 0,17 & 0,10 & 0,12 & 1,79 & 0,07 & & & & \\
\hline & Psychological Meaningfulness & 0,50 & 0,06 & 0,55 & 7,95 & $0,00^{*}$ & & & & \\
\hline
\end{tabular}

$* p<0,05$ - statistically significant

TABLE 4

REgRESSION ANALYSIS WITH WORK ENGAGEMENT AS DEPENDENT VARIABLE AND CO-WORKER RELATIONSHIPS, WORK ROLE FIT AND PSYCHOLOGICAL MEANINGFULNESS AS INDEPENDENT VARIABLES

\begin{tabular}{|c|c|c|c|c|c|c|c|c|c|c|}
\hline \multicolumn{2}{|c|}{ Model } & \multicolumn{2}{|c|}{$\begin{array}{l}\text { Unstandardised } \\
\text { Coefficients }\end{array}$} & \multirow{2}{*}{$\begin{array}{c}\begin{array}{c}\text { Standardised } \\
\text { Coefficients }\end{array} \\
\text { Beta }\end{array}$} & \multirow[t]{2}{*}{$t$} & \multirow[t]{2}{*}{$p$} & \multirow[t]{2}{*}{$\boldsymbol{F}$} & \multirow[t]{2}{*}{$R$} & \multirow[t]{2}{*}{$R^{2}$} & \multirow[t]{2}{*}{$\Delta R^{2}$} \\
\hline & & B & SE & & & & & & & \\
\hline \multirow[t]{3}{*}{1} & & & & & & & $11,23^{*}$ & 0,25 & 0,06 & $0,06^{*}$ \\
\hline & (Constant) & 26,60 & 1,47 & & 18,10 & $0,00^{*}$ & & & & \\
\hline & Co-worker Relationships & 0,13 & 0,04 & 0,25 & 3,35 & $0,00^{*}$ & & & & \\
\hline \multirow[t]{4}{*}{2} & & & & & & & $13,48^{*}$ & 0,37 & 0,14 & 0,08 * \\
\hline & (Constant) & 24,58 & 1,51 & & 16,31 & $0,00^{*}$ & & & & \\
\hline & Co-worker Relationships & 0,08 & 0,04 & 0,14 & 1,87 & 0,06 & & & & \\
\hline & Work Role Fit & 0,32 & 0,08 & 0,30 & 3,85 & $0,00^{*}$ & & & & \\
\hline \multirow[t]{5}{*}{3} & & & & & & & $32,30^{*}$ & 0,61 & 0,37 & 0,23 * \\
\hline & (Constant) & 17,18 & 1.61 & & 10,68 & 0,00 & & & & \\
\hline & Co-worker Relationships & 0,05 & 0,04 & 0,09 & 1,36 & 0,18 & & & & \\
\hline & Work Role Fit & -0.14 & 0,09 & $-0,13$ & $-1,48$ & 0,14 & & & & \\
\hline & Psychological Meaningfulness & 0,59 & 0,08 & 0,65 & 7,77 & $0,00^{*}$ & & & & \\
\hline
\end{tabular}

* $p<0,05$ - statistically significant

The results in Table 3 show that approximately $3 \%$ of the variance in Work Engagement (as measured by the Work Engagement Scale) is predicted by Psychological Safety. A statistically significant increase in the $R^{2}$ was obtained when Psychological Availability was entered into the regression analysis (change in $R^{2}=10 \%$ ). A further statistically significant increase in the $R^{2}$ was obtained when Psychological Meaningfulness was entered into the regression analysis (change in $R^{2}=24 \%$ ). Table 3 demonstrates that Psychological Meaningfulness is the best predictor of Work Engagement.

Next, a series of multiple regression analyses were performed to test whether organisational conditions predicted work engagement and to test whether psychological meaningfulness, safety and availability mediates the relationship between organisational conditions and work engagement. Baron and Kenny (1986) recommend three steps in order to test for mediation. According to these authors, beta coefficients of different regression equations must be compared. Firstly, the mediator should be predicted by the independent variable. Secondly, the dependent variable should be predicted by the mediator and the independent variable, and lastly, the dependent variable should be regressed on the independent variable, controlling for the mediator. If all steps prove significant, perfect mediation holds when, controlling for the mediator, the independent variable does not predict the dependent variable.

The results of a multiple regression analysis with Work Engagement (as measured by the Work Engagement Scale) as dependent variable and Co-worker Relationships, Work Role Fit and Psychological Meaningfulness (as measured by the Work Experience Questionnaire) as independent variables are reported in Table 4.

The results in Table 4 show that $37 \%$ of the variance in Work Engagement (as measured by the Work Engagement Scale) is predicted by Co-worker Relations, Work Role Fit and Psychological Meaningfulness. The results in Table 4 indicate that Co-worker Relations $(\beta=0,30)$ statistically significantly predicted Work Engagement in Step 1. Work Role Fit $(\beta=0,25)$ statistically significantly predicted Work Engagement in Step 2. However, when Co-worker Relations, Work Role Fit and Psychological Meaningfulness were entered into the regression equation, the regression coefficients for Co-worker Relations and Work Role Fit were no longer statistically significant. Co-worker Relations and Work Role Fit were statistically significant predictors of Psychological Meaningfulness (see Table 3) and Work Engagement (see Table 4). However, the regression coefficients of Co-worker Relations and Work Role 
Fit were not statistically significant when they were entered with Psychological Meaningfulness into the regression equation (see Table 4). Therefore, it can be deduced that Psychological Meaningfulness mediates the relationship between Co-worker Relations and Work Role Fit on the one hand and Work Engagement on the other hand. Therefore, Hypothesis $4 \mathrm{a}$ is accepted.

The results of a multiple regression analysis with Work Engagement (as measured by the Work Engagement Scale) as dependent variable and Supervisor Relations, Co-worker Relations, Co-worker Norms, Job Insecurity, and Psychological
Safety (as measured by the Work Experience Questionnaire) as independent variables are reported in Table 5.

The results in Table 5 show that $10 \%$ of the variance in Work Engagement (as measured by the Work Engagement Scale) is predicted by Supervisor Relations, Co-worker Relations, Coworker Norms, Job Insecurity, and Psychological Safety (as measured by the Work Experience Questionnaire). The results in Table 5 indicate that Co-worker Relations $(\beta=0,19)$ and Coworker Norms $(\beta=0,19)$ statistically significantly predicted Work Engagement in Step 1. Although Co-worker Relations and Co-worker Norms were statistically significant predictors

TABle 5

REgRSSION ANALYSIS WITH WORK ENGAGEMENT AS DEPENDENT VARIABLE AND CO-WORKER RELATIONSHIPS, WORK ROLE FIT AND PSYCHOLOGICAL SAFETY AS INDEPENDENT VARIABLES

\begin{tabular}{|c|c|c|c|c|c|c|c|c|c|c|}
\hline \multicolumn{2}{|c|}{ Model } & \multicolumn{2}{|c|}{$\begin{array}{l}\text { Unstandardised } \\
\text { Coefficients }\end{array}$} & \multirow{2}{*}{$\begin{array}{c}\begin{array}{c}\text { Standardised } \\
\text { Coefficients }\end{array} \\
\text { Beta }\end{array}$} & \multirow[t]{2}{*}{$t$} & \multirow[t]{2}{*}{$p$} & \multirow[t]{2}{*}{$F$} & \multirow[t]{2}{*}{$R$} & \multirow[t]{2}{*}{$R^{2}$} & \multirow[t]{2}{*}{$\Delta R^{2}$} \\
\hline & & B & SE & & & & & & & \\
\hline \multirow[t]{3}{*}{1} & & & & & & & 2.59 & 0,12 & 0,015 & 0,015 \\
\hline & (Constant) & 29,68 & 1,12 & & 28,51 & $0,00^{*}$ & & & & \\
\hline & Supervisor Relations & 0,05 & 0,03 & 0,12 & 1,61 & $0,00^{*}$ & & & & \\
\hline \multirow[t]{4}{*}{2} & & & & & & & $5.62 *$ & 0,25 & 0,063 & $0,048 *$ \\
\hline & (Constant) & 26,47 & 1,55 & & 17,04 & $0,00^{*}$ & & & & \\
\hline & Supervisor Relations & 0,10 & 0,04 & 0,02 & 0,27 & 0,06 & & & & \\
\hline & Co-worker Relations & 0,13 & 0,04 & 0,24 & 2,92 & $0,00^{*}$ & & & & \\
\hline \multirow[t]{5}{*}{3} & & & & & & & $5.59 *$ & 0,30 & 0,091 & $0,028 *$ \\
\hline & (Constant) & 24,44 & 1,77 & & 13,81 & $0,00^{*}$ & & & & \\
\hline & Supervisor Relations & $-0,02$ & 0,04 & $-0,04$ & $-0,44$ & 0,66 & & & & \\
\hline & Co-worker Relations & 0,11 & 0,04 & 0,21 & 2,59 & $0,01^{*}$ & & & & \\
\hline & Co-worker Norms & 0,49 & 0,21 & 0,19 & 2,29 & $0,02^{*}$ & & & & \\
\hline \multirow[t]{6}{*}{4} & & & & & & & $4.35^{*}$ & 0,31 & 0,095 & 0,004 \\
\hline & (Constant) & 25,12 & 1,95 & & 12,87 & $0,00^{*}$ & & & & \\
\hline & Supervisor Relations & $-0,02$ & 0,04 & $-0,04$ & $-0,47$ & 0,64 & & & & \\
\hline & Co-worker Relations & 0,11 & 0,04 & 0,20 & 2,44 & $0,02^{*}$ & & & & \\
\hline & Co-worker Norms & 0,51 & 0,22 & 0,20 & 2,38 & $0,02^{*}$ & & & & \\
\hline & Job Insecurity & $-0,07$ & 0,09 & $-0,06$ & $-0,82$ & 0,41 & & & & \\
\hline \multirow[t]{7}{*}{5} & & & & & & & $3.72 *$ & 0,32 & 0,101 & 0,007 \\
\hline & (Constant) & 24,08 & 2,17 & & 11,10 & $0,00^{*}$ & & & & \\
\hline & Supervisor Relations & $-0,03$ & 0,04 & $-0,07$ & $-0,76$ & 0,45 & & & & \\
\hline & Co-worker Relations & 0,10 & 0,04 & 0,19 & 2,25 & 0,03 * & & & & \\
\hline & Co-worker Norms & 0,50 & 0,22 & 0,19 & 2,31 & $0,02 *$ & & & & \\
\hline & Job Insecurity & $-0,05$ & 0,90 & $-0,04$ & $-0,51$ & 0,61 & & & & \\
\hline & Psychological Safety & 0,21 & 0,19 & 0,09 & 1,09 & 0,28 & & & & \\
\hline
\end{tabular}

${ }^{*} p<0,05-$ statistically significant

TABle 6

REGRESSION ANALYSIS WITH CONSCIOUSNESS AND RESOURCES AND PSYCHOLOGICAL AVAILABILITY AS INDEPENDENT VARIABLES AND WORK ENGAGEMENT AS DEPENDENT VARIABLE

\begin{tabular}{|c|c|c|c|c|c|c|c|c|c|c|}
\hline \multicolumn{2}{|c|}{ Model } & \multicolumn{2}{|c|}{$\begin{array}{l}\text { Unstandardised } \\
\text { Coefficients }\end{array}$} & \multirow{2}{*}{$\begin{array}{c}\text { Standardised } \\
\text { Coefficients }\end{array}$} & \multirow[t]{2}{*}{$t$} & \multirow[t]{2}{*}{$p$} & \multirow[t]{2}{*}{$\boldsymbol{F}$} & \multirow[t]{2}{*}{$\boldsymbol{R}$} & \multirow[t]{2}{*}{$R^{2}$} & \multirow[t]{2}{*}{$\Delta R^{2}$} \\
\hline & & B & SE & & & & & & & \\
\hline \multirow[t]{3}{*}{1} & & & & & & & 2.22 & 0,11 & 0,013 & 0,013 \\
\hline & (Constant) & 32,51 & 0,82 & & 39,73 & $0,00^{*}$ & & & & \\
\hline & Self-consciousness & $-0,21$ & 0,14 & $-0,11$ & $-1,50$ & 0,14 & & & & \\
\hline \multirow[t]{4}{*}{2} & & & & & & & $4,30^{*}$ & 0,22 & 0,049 & $0,036^{*}$ \\
\hline & (Constant) & 28,82 & 1,67 & & 17,21 & $0,00^{*}$ & & & & \\
\hline & Self-consciousness & $-0,10$ & 0,15 & $-0,05$ & $-0,65$ & 0,52 & & & & \\
\hline & Resources & 0,12 & 0,05 & 0,20 & 2,51 & $0,01^{*}$ & & & & \\
\hline \multirow[t]{5}{*}{3} & & & & & & & $7.78 *$ & 0,35 & 0,123 & 0,074 * \\
\hline & (Constant) & 20,28 & 2,80 & & 7,27 & $0,00^{*}$ & & & & \\
\hline & Self-consciousness & 0,08 & 0,15 & 0,04 & 0,51 & 0,61 & & & & \\
\hline & Resources & 0,51 & 0,05 & 0,09 & 1,04 & 0,30 & & & & \\
\hline & Psychological Availability & 0,45 & 0,12 & 0,32 & 3,75 & 0,01 * & & & & \\
\hline
\end{tabular}

${ }^{*} p<0,05$ - statistically significant 
of Psychological Safety (see Table 3) and Work Engagement (see Table 4), the regression coefficients of Co-worker Relations and Co-worker Norms remained statistically significant when they were entered with Psychological Safety into the regression analysis. Therefore, no evidence was found that Psychological Safety mediates the relationship between Supervisor Relations, Co-worker Relations and Co-worker Norms on the one hand and Work Engagement on the other hand. Therefore, Hypothesis $4 \mathrm{~b}$ is rejected.

The results of a multiple regression analysis with Work Engagement (as measured by the Work Engagement Scale) as dependent variable and Resources, Self-consciousness, and Psychological Availability (as measured by the Work Experience Questionnaire) as independent variables are reported in Table 6.

Table 6 demonstrates that 5\% of the variance in Work Engagement is explained by Self-Consciousness and Resources. When Psychological Availability was entered into the analysis, $12 \%$ of the variance in Work Engagement was explained. Only the regression coefficient of Psychological Availability $(\beta=$ 0,32 ) was statistically significant when it was entered with Self-consciousness and Resources into the regression equation. Self-consciousness and Resources were statistically significant predictors of Psychological Availability (see Table 3) and Work Engagement (see Table 6). However, the regression coefficients of Self-consciousness and Resources were not statistically significant when they were entered with Psychological Availability into the regression equation (see Table 6). Therefore, it can be deduced that Psychological Availability mediates the relationship between Self-consciousness and Resources on the one hand, and Work Engagement on the other hand. Therefore, hypothesis $4 \mathrm{c}$ is accepted.

\section{DISCUSSION}

The objective of this study was to investigate the antecedents of work engagement. The results of this study confirmed that two psychological conditions, i.e. meaningfulness and availability mediated the relationship between antecedent conditions and work engagement. This study found partial support for the findings of May et al. (2004) in as far as the mediating effects of both psychological meaningfulness and availability on work engagement were confirmed, with meaningfulness as the strongest predictor of work engagement. Work role fit was positively linked with psychological meaningfulness and the availability of job resources and less self-consciousness were positively linked with psychological availability, which mediates the effect on work engagement. The above findings provide support for the contribute to our understanding of the psychological conditions relating to work engagement.

Similar to the findings of May et al. (2004) it was found that psychological meaningfulness was the strongest predictor of work engagement. This finding confirms the results of previous studies on work engagement and the mediating effect of meaningfulness (May et al., 2004; Schaufeli, Salanova, GonzalezRoma \& Bakker, 2000). Work role fit was the strongest predictor of psychological meaningfulness. This confirms the results of previous studies (May et al., 2004; Strümpfer, 2003). When employees see their roles as opportunities to express themselves they will experience a sense of meaning (Snyder \& Lopez, 2005). Strümpfer (2003) highlights the view of work becoming a frequently chosen alternative source of meaning. This happens particularly in the lives of idealistic and highly motivated individuals who work hard because they expect their work to give meaning to their existence.

The results of this study also confirmed the importance of psychological availability as a predictor of work engagement.
Kahn (1990) regarded psychological availability as the sense of having the resources to personally engage at a particular moment. Psychological availability mediated the relationship between resources (i.e. cognitive, emotional and physical resources) and self-consciousness on the one hand and work engagement on the other hand. These resources had the strongest effect on psychological availability, while feelings of self-consciousness impacted negatively on psychological availability, implying that someone who is less self-conscious is psychologically more available to engage at work.

Psychological safety was a statistically significant predictor of work engagement. However, it did not mediate the relationship between supervisor relations, co-worker relations, and coworker norms on the one hand and work engagement on the other hand. This is inconsistent with the findings of May et al. (2004), where it was found that safety displayed a strong relation with work engagement and partially mediated the effect of adherence to co-worker norms and work engagement. One possible explanation for this finding is that the reliability of the scale which measures psychological safety was questionable in this study.

The results of this study not only indicated that work role fit was a statistically significant predictor of psychological meaningfulness and work engagement, but also that psychological meaningfulness mediates the relationship between work role fit and work engagement. This finding is in line with the findings of May et al. (2004) whereby the strong relationship between work role fit and meaningfulness was confirmed and the mediating effect on work engagement was statistically proven.

Similarly, the results confirmed that self-consciousness and resources (in particular) were statistically significant predictors of psychological availability and work engagement. It was confirmed that psychological availability mediates the relationship between self-consciousness and resources on the one hand, and work engagement on the other hand.

It implies that even if antecedents such as work role fit, resources and self-consciousness were present and could act as predictors of engagement, the effects of such characteristics were mediated by the psychological conditions of meaningfulness and availability. People therefore need to find their work meaningful and have the resources to make themselves available to engage with their work.

This study had various limitations. First, the scale which measured psychological safety was not sufficiently reliable to be used in. More research is needed regarding the measurement of psychological safety. Second, a cross-sectional design was used in this study, which makes it impossible to assess the causality of relationships. It is recommended for future research to include further investigation of the mediating effects of psychological conditions such as meaningfulness, safety and availability on work engagement in other contexts, as well as with larger samples, or even by the use of longitudinal studies to establish causal relations.

\section{RECOMMENDATIONS}

This study explored the mediating effects of three psychological conditions on work engagement. Through increased understanding of the effects of these mediators, possible reasons for disengagement at work can be isolated. More specifically, opportunities can be identified to optimise the specific job/ personal characteristics and psychological conditions to increase and maintain engagement at the workplace.

The findings of this study have important implications for organisations and managers in terms of design of jobs, employee selection and relations with employees. May et al. (2004) discussed 
in detail ways in which managers can foster meaningfulness, safety and availability to enhance engagement. Based on the findings of this study, managers are advised to consider ways to enhance meaningfulness by ensuring effective design of jobs, selecting the proper employees for particular work roles and taking more time to learn about personal aspirations and desires of employees in order to fit them to roles that will allow self expression. Maslach and Leiter (1997) also suggest the promotion of human values whereby it is the responsibility of leaders to model, mentor and coach employees along the lines of value clarification and implementation. Availability should be supported by ensuring there is sufficient support for employees to invest in the development of their own skills and resources (cognitive, emotional and physical) to improve perceptions of psychological availability.

Research is needed to determine the reliability and validity of the Work Experience Scale in other samples in South Africa. Large sample sizes might provide increased confidence that study findings would be consistent across other similar groups. Further construct validity research is required to establish the factorial validity of the Work Experience Scale, in particular within a South African context. The findings of this study also suggest the need for possible improvement of item content of the measuring instruments. This implies that the wording of certain items must be modified in order to make it more appropriate for the South African context. Research is needed regarding the effects of individual and/or organisational interventions on psychological conditions such as meaningfulness, safety and availability should be done, most likely as part of longitudinal studies.

\section{REFERENCES}

Baron, R.M. \& Kenny, D.A. (1986). The moderator-mediator variable distinction in social psychological research: Conceptual, strategic, and statistical considerations. Journal of Personality and Social Psychology, 51, 1173-1182.

Bleeker, M.M.E. \& Roodt, G. (2002). Die verband tussen werksbetrokkenheid en werksprestasie. [The relationship between work involvement and work performance]. $S A$ Journal of Industrial Psychology, 28(1), 22-32.

Brown, S.P. (1996). A meta-analysis and review of organisational research on job involvement. Psychological Bulletin, 120, 235-255.

Carr, A. (2004). Positive psychology: The science of happiness and human strength. New York: Brunner-Routledge.

Clark, L.A. \& Watson, D. (1995). Constructing validity: Basic issues in objective scale development. Psychological Assessment, 7, 309-319.

Cohen, J. (1988). Statistical power analysis for the behavioural sciences (Rev. ed.). Orlando, CA: Academic Press.

Edmondson, A. (1999). Psychological safety and learning behaviour in work teams. Administrative Science Quarterly, 44, 350-383.

Fay, D. \& Luhrmann, H. (2004). Current themes in organizational change. European Journal of Work and Organizational Psychology, 13(2), 113-119.

Harter, J. K. (2001). Taking feedback to the bottom line. Gallup Management Journal, March,. Available at: http://www. gallupjournal.com/GMJarchive/issue1/2001315i.asp. [2006, 21 July].

Kahn, W.A. (1990). Psychological conditions of personal engagement and disengagement at work. Academy of Management Journal, 33, 692-724.
Locke, E.A. \& Taylor, M.S. (1990). Stress, coping and the meaning of work. In A. Brief and W.R. Nord (Eds.), Meanings of occupational work (pp. 135-170). Lexington, MA: Lexington Books.

Maslach, C. \& Leiter, M.P. (1997). The truth about burnout. San Francisco: Jossey-Bass.

Maslach, C., Schaufeli, W.B. \& Leiter, M.P. (2001). Job burnout. Annual Review of Psychology, 52, 397-422.

May, D.R., Gilson, R.L. \& Harter, L.M. (2004). The psychological conditions of meaningfulness, safety and availability and the engagement of the human spirit at work. Journal of Occupational and Organizational Psychology, 77, 11-37.

McAllister, D.J. (1995). Affect-and cognition-based trust as foundations for interpersonal cooperation in organizations. Academy of Management Journal, 38, 24-59.

Naudé, J.L.P. \& Rothmann, S. (2006). Work-related well-being of emergency workers in Gauteng. South African Journal of Psychology, 36, 63-81.

Newell, S. (2002). Creating the healthy organization: Well-being, diversity and ethics at work. London: Thomson Learning.

Nunnally, J.C. \& Bernstein, I.H. (1994). Psychometric theory (3 ${ }^{\text {rd }}$ ed.). New York: McGraw-Hill.

Rothmann, S. \& Storm, K. (2003, May). Work engagement in the South African Police Service. Poster presented at the $11^{\text {th }}$ European Congress of Work and Organisational Psychology, Lisbon, Portugal.

Schaufeli, W.B. \& Bakker, A.B. (2004). Job demands, job resources and their relationship with burnout and engagement: A multi-sample study. Journal of Organizational Behavior, 25, 293-315.

Schaufeli, W.B., Salanova, M., Gonzalez-Roma, V. \& Bakker, A.B. (2000). The measurement of engagement and burnout: a two sample confirmatory factor analytic approach. Journal of Happiness Studies, 3, 71-92.

Schlenker, B.R. (1980). Impression management: The self-concept, social identity and interpersonal relations. Monterey, CA: Brooks/Cole Publishing.

Seeman, M. (1972). Alienation and engagement. In A. Campbell $\&$ P.E. Converce (Eds.), The human meaning of social change (pp. 467-527). New York: Russell Sage Foundation.

Shamir, B. (1991). Meaning, self and motivation in organizations. Organization Studies, 12. 405-424.

Snyder, C.R. \& Lopez, S.J. (2005). Handbook of positive psychology. New York: Oxford University Press.

Spreitzer, G.M., Kizilos, M.A. \& Nason, S.W. (1997). A dimensional analysis of the relationship between psychological empowerment and effectiveness, satisfaction and strain. Journal of Management, 23, 679-704

SPSS (2003). SPSS 12.0 for Windows. Chicago, IL: SPSS Incorporated.

Steyn, H.S. (1999). Praktiese betekenisvolheid: Die gebruik van effekgroottes. Wetenskaplike bydraes - Reeks B: Natuurwetenskappe Nr. 117. Potchefstroom: PU vir CHO.

Storm, K. \& Rothmann, S. (2003). A psychometric analysis of the Utrecht Work Engagement Scale in the South African Police Service. South African Journal of Industrial Psychology, 29(4), 62-70.

Strümpfer, D.J.W. (1990). Salutogenesis: A new paradigm. South African Journal of Psychology, 20, 265-276.

Sutton, R.I. (1991). Maintaining norms about expressed emotions: The case of the bill collectors. Administrative Science Quarterly, 36, 245-268.

Thomas, K.W. \& Velthouse, B.A. (1990). Cognitive elements of empowerment: An "interpretive" model of intrinsic task motivation. Academy of Management Review, 15, 666-681.

Van Wyk, R., Boshoff, A.B. \& Cilliers, F.V.N. (2003),. The prediction of job involvement for pharmacists and accountants. $S A$ Journal of Industrial Psychology, 29(3), 61-67. 